\title{
Leaf area index of Norway spruce stands in relation to age and defoliation
}

\author{
*R. Pokorný ${ }^{1,2)}$, S. Stojnič ${ }^{31}$ \\ 1) Global Change Research Centre AS CR, v.v.i., Bëlidla 986/4a, CZ-603 00 Brno, Czech Republic, E-mail: \\ pokorny.r@czechglobe.cz \\ 2) Mendel University in Brno, Zemédèlská 3, CZ-61300 Brno, Czech Republic \\ ${ }^{3)}$ Institute of Lowland Forestry and Environment, University of Novi Sad, Antona Cehova 13, 21000 Novi \\ Sad, Republic of Serbia, E-mail:srdjan_stojnic@yahoo.com
}

\begin{abstract}
Pokorný R., Stojnič S. 2012: Leaf area index of Norway spruce stand in relation to its age and defoliation. - Beskydy, 5 (2): 173-180

This contribution presents LAI data of 17 Norway spruce stands of different age (from 15 to 102 years) and health status (defoliation ranging from 0 to $40 \%$ ) located in the Těšínské Beskydy Mts. (NE of the Czech Republic). Defoliation degree was estimated by ocular observation and LAI was estimated indirectly on the base of gap fraction method using LAI-2000 PCA (Li-Cor, USA). It was found that LAI decreased with stand age (approximately from 12.6 to 8.5 ) whereas defoliation increased. Therefore, strong relationship between defoliation and LAI as well as gap fractions was found. LAI appears valuable parameter for health status of stand evaluation due to linear relationship $\left(r^{2}=0.87\right)$ between LAI and defoliation. As LAI can be estimated more objectively by a canopy analyzer then the degree of canopy defoliation by ocular observation, there is a perspective for a wide use LAI in forest practice. The LAI values can be used for the evaluation of health status of Norway spruce stands.
\end{abstract}

Keywords: health status, LAI, needle, Picea abies

Abbreviations: DEF - defoliation, DIFN - diffuse non-interceptance (canopy openness), LAI - leaf area index (hemi surface), LAIe - effective leaf area index (uncorrected direct product of instrument), NOx - nitrogen oxides

\section{Introduction}

Leaf area index (LAI) quantifies the amount of leaf area bearing by tree or whole stand normalized by unit of crown projected or whole stand ground area (e.g. Norman and Campbell 1989). It is one of the most important structural characteristic of a tree or forest stand due to potential of biomass production or health status evaluation and/or their prediction. LAI can be estimated using many experimental methods, which can be simply separated into four groups: (1) direct methods, (2) semi-direct methods, (3) indirect methods, and (4) subjective-evaluation methods (see reviews of Norman, Campbell 1989 or Jonckheere et al. 2004). Defoliation is quantified in percentage, when in practice, evaluators of tree defoliation keep in their head a picture of fully foliated tree (100\%), i.e. with maximum LAI, and then they compare this picture, like an etalon, with the actual picture of a tree in a field. The results are based on subjectively evaluated defoliation, however, all evaluators are trained together, i.e. take into the head the same etalon. It is possible to presume that if the same group of evaluators will evaluate defoliation in a whole region or in a large forest area during a short time period with quite stable LAI values, the results are loaded with a systematic error and results are comparable. The above mentioned procedure is commonly used for evaluation of 
tree/stand defoliation and forest stands health conditions degree in the Czech Republic (Ministry of Agriculture of the Czech Republic notice no. 78/1996).

Even if LAI is evaluated by an indirect method, which is based on canopy gap-fraction or transmittance of light quantification, obtained values are much more objective, accurate and widely comparable to other ones comparing to subjective evaluation of defoliation (DEF). It was the reason for health status revision of Norway spruce forests by some objective technique in forest region Nýdek in the Beskydy Mountains, where symptoms of declining, as yellowing, drying and dying of trees started to occur (Šrámek et al. 2008). Described situation differs from similar one in the Ore Mts. (Šrámek et al. 1999) as even young Norway spruce forests started to decline, especially in low vegetation zones (4-6) at appropriate soils (Šrámek et al. 2008).

This contribution presents supporting data of LAI estimation by an indirect method in Norway spruce stands differing in age and health status, based on evaluation by ocular estimation of defoliation degree, expressed in percentage. The main hypothesis for the present work comes from a simple presumption of imperative relationship between LAI and defoliation of stand.

\section{Material and Methods}

All measurements were carried out on 17 selected even-aged stands with high representation of Norway spruce (Picea abies [L.] Karst.), located within forest district Nýdek in the Těšínské Beskydy Mountains (NE of the Czech Republic). For detail description of stands see Tab. 1.

There, Šrámek et al. (2008) analyzed the trends in development of climatic parameters in comparison with long-term normal period (19611990; Tolasz 2007). The increase in all monthly averaged temperatures about $0.5^{\circ} \mathrm{C}$ was found, except September and November, during the last decennium. No trend for precipitation was found, however it exhibited high variability (from $-6 \%$ to $+9 \%$ ). Average annual increment of precipitation during 1998-2008 was $0.5 \%$ ( $0.9 \%$ for a growing season). Significant drought periods were occurring since 1990, particularly in 2003. Norway spruce forest stands started to decline in coincidence to these droughts.

Sulfur dioxide $\left(\mathrm{SO}_{2}\right)$ and nitrogen oxides $\left(\mathrm{NO}_{\mathrm{x}}\right)$ concentrations in atmosphere did not affect significantly forests health status in presented region. Contrariwise, detected high ozone $\left(\mathrm{O}_{3}\right)$ concentrations had the possibility to affect health condition of forest stands, but any visible symptoms were not occurred either on broadleaf tree species, which are much more sensitive to ozone influence than coniferous trees.

Leaf area index was estimated during three days long measuring campaign in the end of $\mathrm{Au}$ gust 2010. The estimation of final hemi-surface LAI values was made by LAI-2000 Plant canopy analyzer (Li-Cor, Lincoln, NE, USA), based on verified methodology (Pokorný, Marek 2000). Above-canopy readings were taken before and after the measurements of all points within transect in open plots near the stands. In the case of clear sky, the measurements were carried out close to sunrise and sunset, when the radiation readings of the first LAI-2000 ring sensor slowly changed from 3 to 30 and vice versa in the open plot. Below-canopy measurements with LAI2000 were made about $0.5 \mathrm{~m}$ above the ground in young stands and about $2 \mathrm{~m}$ above the ground in old stands with 2-5 m distance between measurement points (the distance between points enhanced with increasing canopy homogeneity) on three representative transects across the plots. Transects were evenly distributed within the stand, perpendicularly oriented to tree-rows or along the level curves depending on stand structure. The length of individual transect varied from $30 \mathrm{~m}$ to $90 \mathrm{~m}$ depending on plot size. The measurements were repeated several times during full overcast or clear sky conditions. Correction scheme proposed by Leblanc and Chen (2001) was not necessary to use because direct sun rays did not reach top of the canopy. The $90^{\circ}$ of azimuthal view was restricted in all measurements below low canopies to exclude the operator from the viewing area. The calculation of the effective LAI (LAIe; Chen 1996) from the LAI2000 measurements was implemented by the PC program C2000.exe (LI-COR, USA) using the interpolation method of above-canopy readings (i) in case of clear sky, due to fluently changing radiation intensity, or using the time-closest above-canopy reading method (c) in case of overcast sky conditions, due to unevenly changing radiation conditions. All LAIe values were recalculated with the masking of the last two rings (i.e. 5 th and 4 th rings; $47-74^{\circ}$ of zenithal view) to avoid underestimation of LAI due to large gaps between the whorls in the direction close to horizon. LAIe was than multiplied by a correction factor of 1.6 (Pokorný, Marek 2000) to obtain hemi-surface LAI (i.e. half of the total needle surface area normalized by the ground area). DIFN (Diffuse Non-interceptance $\sim$ canopy openness) value, as a by-product of 
LAI-2000, could be used for forest homogeneity or canopy coverage quantification (see Table 1). DIFN quantifies visible proportion of the sky by means of a sensor (values ranging within interval 0-1; 1 - free area, 0 - full coverage, see LAI-2000 operating manual). DIFN is indirectly proportional to LAI (light transmittance method gap fraction method; Gower, Norman 1991).

We noted that it is impossible to accurately quantify LAI in stands with highly nonhomogeneous canopies, i.e. sparse and/or clumped resulting large canopy gaps. Therefore, only stands with rather homogeneous canopies were measured. However it is not theoretically suitable to use constant correction factor for stands of different age, mainly due to increasing proportion of stem and branch surface area to leaf area within the canopy (Chen, Cihlar 1995a, b), we used correction factor of 1.6 independently on stand age as it was found appropriate for young (Pokorný, Marek 2000) as well as for old spruce stands (Gower, Norman 1991).

\section{Results and Discussion}

Age of the investigated stands varied between 15 and 102 years. Percentage of stand defoliation ranged between 0 and $40 \%$. No defoliation was observed in two stands only, those in age of 15 and 33. The highest value of LAI was observed in the youngest stands (i.e. LAI of $13.11 \mathrm{~m}^{2} \mathrm{~m}^{-2}$ derived from LAIe of 8.20), while the lowest LAI values were recorded in the two old stands (with LAI of $5.01 \mathrm{~m}^{2} \mathrm{~m}^{-2}$, LAIe of 3.13).

It is well established that fast-growing tree species reach the maximum LAI at the age of 10 - 15 years, whereas slow-growing ones at the age of 20-40 years or later (Long, Smith 1992, Vose et al. 1994, Vertessy et al. 2001). Afterwards LAI fluctuates (in the case of fast growing tree species) around the naturally optimal (equilibrium) value, or it slowly decreases (in the case of slow-growing tree species) and remains constant. Battaglia et al. (1998) and Sonohat et al. (2004) also presented that stand's LAI increases with development of stand and tends to stabilize or decline slowly as trees become older. Fast growing tree species, particularly in young age, are commonly cultivated as evenaged stands - monocultures (e.g. Picea abies, Pinus

Tab. 1: Stand characteristics of observed Norway spruce (P. abies, see representation in the Table) stands. Defoliation - degree of defoliation estimated by eye; LAIe - effective leaf area index (direct product of LAI-2000 PCA); SE-standard error of LAIe estimation; DIFN - diffuse non-interceptance (quantification of visible part of the sky, i.e. 1 - free area, 0 - full coverage), Admixture of othertree species: AA - Abies alba, AG - Abies grandis, AI-Alnus incana, AP - Acerpseudoplatanus, BV-Betula verrucosa, FE - Fraxinus excelsior, FS - Fagus sylvatica, LD - Larix decidua.

\begin{tabular}{ccccccc}
\hline $\begin{array}{c}\text { Stand age } \\
(\mathbf{y r})\end{array}$ & P. abies (\%) & Defoliation (\%) & LAIe & SE & DIFN & Admixture \\
\hline 15 & 100 & 0 & 8.20 & 0.30 & 0.0065 & \\
18 & 94 & 10 & 7.15 & 0.21 & 0.0125 & BV, FS \\
21 & 100 & 15 & 7.43 & 0.24 & 0.0113 & \\
22 & 95 & 10 & 7.38 & 0.19 & 0.0113 & AP, FS \\
22 & 95 & 15 & 6.02 & 0.23 & 0.0255 & FS, AG, AP \\
22 & 99 & 25 & 5.37 & 0.24 & 0.0380 & FS \\
27 & 100 & 20 & 5.15 & 0.17 & 0.0425 & \\
27 & 100 & 35 & 4.08 & 0.21 & 0.0810 & \\
29 & 90 & 15 & 6.14 & 0.14 & 0.0250 & $F S$ \\
30 & 94 & 25 & 4.72 & 0.19 & 0.0560 & $F S, A P, F E, A I$ \\
31 & 98 & 25 & 5.49 & 0.11 & 0.0350 & $F S, L D$ \\
33 & 100 & 0 & 6.98 & 0.18 & 0.0157 & \\
46 & 100 & 20 & 5.15 & 0.11 & 0.0450 & \\
47 & 100 & 30 & 3.86 & 0.13 & 0.0965 & \\
91 & 97 & 40 & 3.13 & 0.05 & 0.1510 & $F S$ \\
92 & 92 & 40 & 3.13 & 0.08 & 0.1503 & $F S, A A$ \\
102 & 94 & 40 & 4.35 & 0.13 & 0.0730 & $F S, A A$ \\
\hline
\end{tabular}


sylverstris etc.). In these stands, LAI reached its maximum relatively early (Bond-Lamberty et al. 2002). Norway spruce falls among rather fast growing tree species as documented by reaching the maximum LAI at 15 year of age (Fig. 1). Presented data showed a decrease in LAI values with increasing age of spruce stand. However, LAI values were corrected to extract an effect of defoliation, maximum LAI values of spruce stands decrease since 15-20 years of stand age as they become older (i.e. about $1 / 3$, ca from 12.6 at 15 year to 8.5 of LAI at 120 year old spruce stand; Fig. la). Defoliation was found increasing with stand age (Fig. Ib).

According to Ryan et al. (1997) leaf area index in even-aged stands undergoes gradually and after canopy closure declines continuously. Such dropping of LAI is usually associated with space competition that leads to self-prunning, decreasing stand density, increasing tree mortality etc. (Ryan et al. 1997, Meng et al. 2006, Pokorný et al. 2008), or driving by ontogenetic changes in LAI of individual trees (Nock et al. 2008). Generally, it could be concluded that crown structure of trees develops as a result of the long-term interactions between tree ontogenesis, growth conditions and disturbances that cause defoliation, damage, dieback etc. (Ishii et al. 2000). The decline of LAI could go in consequence of two phenomena: 1) decreasing density of live branches and the increasing density of dead branches (Ishii, Wilson 2001) and 2) decreasing production of needles and branches caused by low light, allocation of carbon and nitrogen following to reproductive onset (Thomas, Ickes 1995, Leal, Thomas 2003).

Relationship between LAI and stand age in Norway spruce stands has showed that LAI declines gradually with increasing of stands age (Fig. la). This is in accordance with the results obtained by Homolova et al. (2007), who found that LAI in Norway spruce stands declined with stand age (from 28 to 100 years). In accordance with this, Kantor et al. (2009) found that LAI in spruce and beech stands increased in the course of the whole time series (observed up to age of 21 years) of the stand development. On the other hand, research conducted in mature stands of beech (Fagus sylvatica L.), pedunculate oak (Quercus robur L.) and Scots pine (Pinus sylvestris $\mathrm{L}$.), showed that stand age was important predictor of LAI only in case of pedunculate oak stands (Bequet et al. 2012). The reason of this could be that individual dominant and codominant trees overcome the equilibrium LAI and invasion of competitive species is going up (Balandier et al. 2006).
Canopy gap fraction quantified by DIFN value varied in a wide range between 0.0065 and 0.0965 (Table 1). This value reflected not only gaps in the canopy closure, but also gaps between whorls, especially in low parts of canopy under zenithal viewing angles near horizon. Theoretically as well as practically, strong relationship between LAI and DIFN values exists $\left(\mathrm{LAI}=-2.639 \ln (\mathrm{DIFN})+0.0033 ; \mathrm{r}^{2}=0.998, \mathrm{n}=17\right)$. Similarly, DIFN relates proportionally to defoliation (DEF; DEF = $12.588 \ln (\mathrm{DIFN})+63.605$; $\left.\mathrm{r}^{2}=0.83, \mathrm{n}=17\right)$. The investigated stand/canopy densities respond to DIFN (on average $0.05 \pm$ 0.04 (SE) with maximum of 0.15). The relationship between LAI and defoliation of spruce stands was found linear (Fig. 2.).

To avoid an effect of stand density on the accuracy of LAI estimation and on the relationship between LAI and defoliation (Fig. 2), all the sparse stands, i.e. stands with stocking density below 0.9 , were preliminarily excluded from our consideration. Therefore, the effect of stand density was eliminated. The highest standard error of LAI estimation was 0.48. The maximum and optimum LAI of young Norway spruce stands according to different stand densities were discussed in our previous study presenting the results from the long term monitoring of seasonal LAI dynamics (Pokorný et al. 2008). Even changing stand density, LAI maximum did not overcome value of 12.5. Similarly, in presented data (Fig. 2), the 15 year-old poor spruce monoculture reached the highest value of LAI (13.1; i.e. LAIe of 8.2). The accuracy of such indirect method for LAI estimation in comparison with the direct method for LAI estimation was discussed in a previous study about testing the accuracy of LAI-2000 instrument (Pokorný, Marek 2000). The indirect methods in comparison with the direct ones for accurate LAI estimation failed in dense canopies consisting from coniferous tree species with LAIe over ca 6.0-6.5 (Deblone et al. 1994, Cutini et al. 1998, Bréda 2003), or exactly over ca 7.9 in spruce forests (Pokorný et al. 2008). Therefore, indirect method for estimation of LAIe using a canopy analyser was found an appropriate method for the most dense spruce canopies (7.9 8.2).

The presented results support the hypothesis of strong relationship between LAI and defoliation of stand. Therefore, in conclusion, LAI can be estimated more objectively rather by an indirect method than rough ocular estimation of defoliation degree. LAI appears valuable parameter for evaluation of health status of a stand. Currently innovated instrument ALAI-02D (Pokorný et al. 2001) has a potential to unify and 

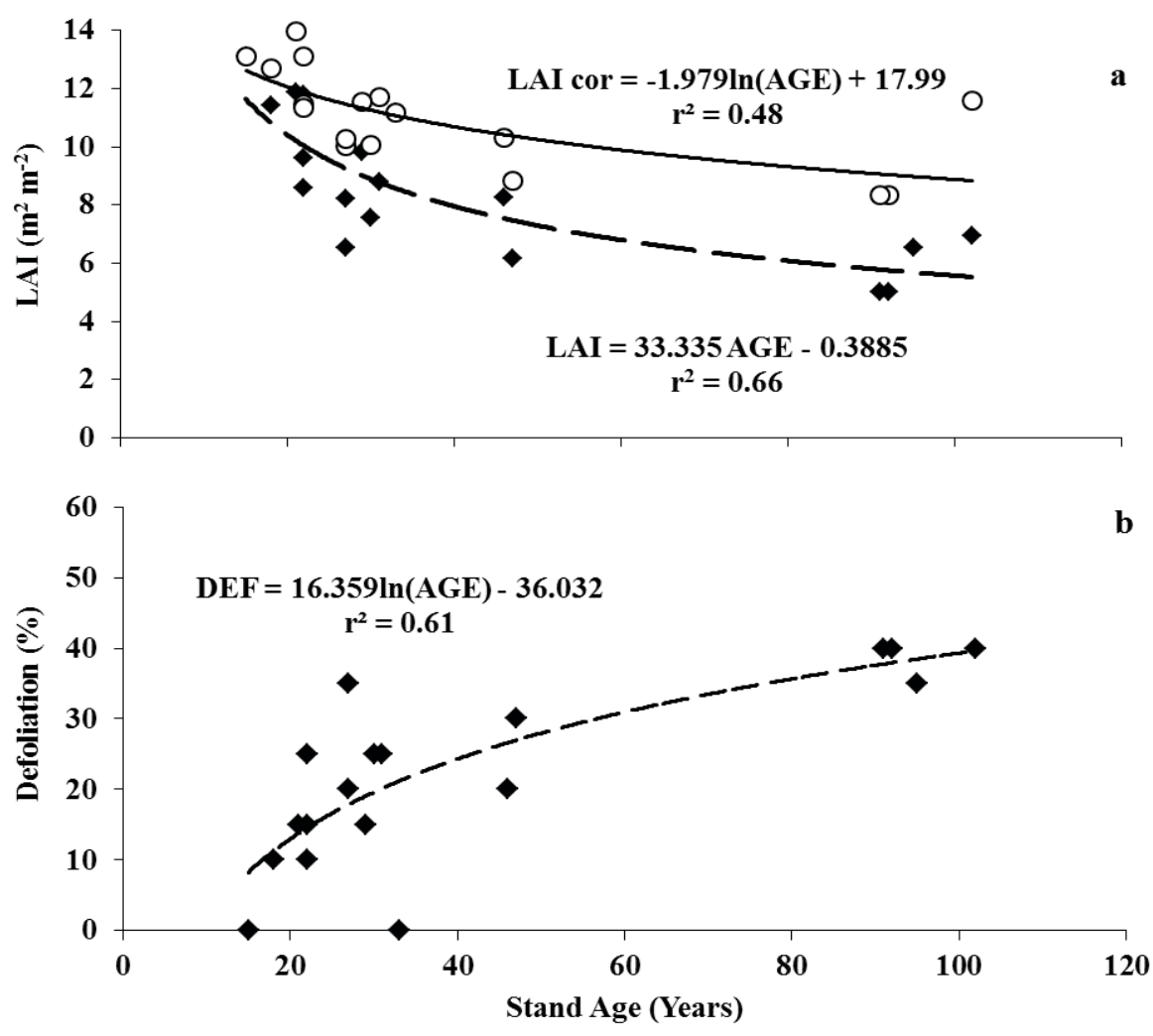

Fig. 1: Dependence of leaf area index (LAI, hemi surface), corrected LAI (LAIcor, i.e. without effect of defoliation) and stand defoliation (DEF) degree estimated by ocular observation on Norway spruce stand age.

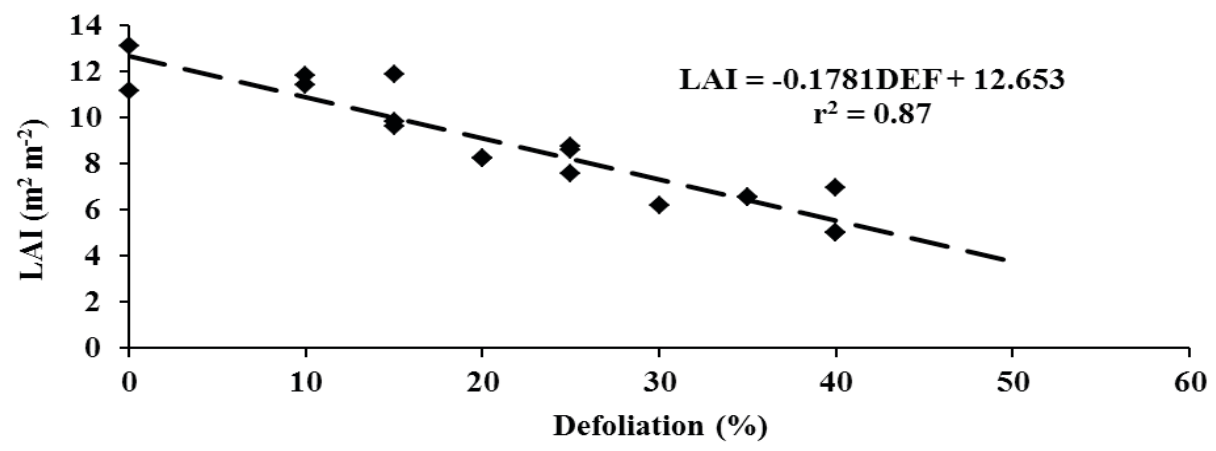

Fig. 2: Relationship between LAI and defoliation of Norway spruce stand independently on stand age.

objectivize LAI estimation and then health status evaluation of Norway spruce forest stands widely in a forest practice.

\section{Acknowledgement}

This publication is an output of the CzechGlobe Centre that is being developed within the OP RDI and co-financed from EU funds and the State Budget of the Czech Republic (Project: CzechGlobe, Reg. No. CZ.1.05/1.1.00/02.0073). The authors are grateful for the financial support also by grants no. TA02010945 of the Technological Agency of the Czech Republic and COST Action FP0903 under program "Climate Change and Forest Mitigation and Adaptation in Polluted Environment". Thanks to Justyna Pietras for English revision. 


\section{References}

Balandier, P., Collet, C., Miller, J. H. et Al. 2006: Designing forest vegetation management strategies based on the mechanisms and dynamics of crop tree competition by neighbouring vegetation. Forestry, 79 (1): 3-27.

Battaglia, M., Cherry, M. L., Beadle, C. L., SAnds, P.J., Hingston, A. 1998: Prediction of leaf area index in eucalypt plantations: effects of water stress and temperature. Tree Physiology, 18: 521-528.

Bequet, R., Kint, V., Campioli, M. et al. 2012: Influence of stand, site and meteorological variables on the maximum leaf area index of beech, oak and Scots pine. European Journal of Forest Research, 131 (2): 283-295.

Bond-Lamberty, B., Wang, C., Gower S. T., NorMAN, J. 2002: Leaf area dynamics of a boreal black spruce fire chronosequence. Tree Physiology, 22: 993-1001.

BRÉDA, N. J. J. 2003: Ground-based measurements of leaf area index: a review of methods, instruments and current controversies. Journal of Experimental Botany, 54: 2403-2417. Chen, J.M. 1996: Optically-based methods for measuring seasonal variation of leaf area index in boreal conifer stands.Agricultural and Forest Meteorology, 80: 135-163.

Chen, J. M., Cihlar, J. 1995a: Plant canopy gap size analysis theory for improving optical instruments of leaf area index of plant canopies. Applied Optics, 34: 6211-6222.

Chen, J. M., Cinlar, J. 1995b: Quantifying the effect of canopy architecture on optical measurement of leaf area index using two gap size analysis method. IEEE Transactions on Geoscience and Remote Sensing, 33: 777-787.

Cuttini, A., Matteucci, G., Mugnozza, G. S. 1998: Estimation of leaf area index with the Li-Cor LAI 2000 in deciduous forests. Forest Ecology and Management, 105 (1-3): 55-65

Deblone, G., Penner, M., Royer, A. 1994. Measuring leaf area index with the LI-COR LAI 2000 in pine stands. Ecology, 75: 1507-1511.

Gower, S. T., Norman J. M. 1991: Rapid estimation of leaf area index in conifer and broadleaved plantations. Ecology, 72: 1896-1900.

Homolova, L., Malenovsky, Z., Hanus, J., Tomaskova, I., Dvorakova, M., PoKorny, R. 2007 : Comparison of different ground techniques to map leaf area index of Norway spruce forest canopy. In: Schaepman, M.E., Liang, S., Groot, N.E., Kneubuhler, M. (Eds.). 10th International Symposium on Physical Measurements and Spectral Signatures in Remote Sensing. Davos, Switzerland.pp.499-504.
Ishit, H., Clement, J.P., Shaw, D.C. 2000: Branch growth and crown form in old coastal Douglas-fir. Forest Ecology and Management, 131: 81-91.

Ishit, H., Wilson, M.E. (2001). Crown structure of old-growth Douglas-fir in the western Cascade Range, Washington. Canadian Journal of Forest Research, 31: 1250-1261.

Jonckheere, I., Fleck, S., Nackaerts, K. et al. (2004). Review of methods for in situ leaf area index determination - Part I. Theories, sensors and hemispherical photography. Agricultural and Forest Meteorology, 121 (1-2): 19-35.

Kantor, P., ŠACH, F., ČERnOHOUS, V. 2009: Development of foliage biomass of young spruce and beech stands in the mountain water balance research area. Journal of Forest Science, 55: 51-62.

LI-COR, Inc. (2009). LAI-2200 plant canopy analyzer operating manual. LICOR, Inc., Lincoln, Nebraska, USA.

LeAL, D. B., Thomas, S. C. 2003: Vertical gradients and tree-to-tree variation in shoot morphology and foliar nitrogen in an oldgrowth Pinus strobus stand. Canadian Journal of Forest Research, 33: 1304-1314.

Long, J. N., Sмiтh, F. W. 1992: Volume increment in Pinus contorta var. latifolia: the influence of stand development and crown dynamics. Forest Ecology and Management, 53: 53-64.

Meng, S. X., Rudnicki, M., Lieffers, V. J., Reid, D. E. B., Silins, U. 2006: Preventing crown collisions increases the crown cover and leaf area of maturing lodgepole pine. Journal of Ecology, 94: 681-686.

Nock, C. A., Caspersen, J. P., Thomas, S. C. 2008: Large ontogenetic declines in intra-crown leaf area index in two temperate deciduous tree species. Ecology, 89: 744-753.

Norman, J. M., Campbell, G. S. 1989: Canopy structure. In: PeArcy, R.W., Ehleringer, J., Mooney, H.A., Rundel, P.W. (Editors) Plant Physiological Ecology. Field Methods and Instrumentation, Chapman and Hall, New York, 301-325.

Pokorný, R., Marek, M. V. 2000: Test of accuracy of LAI estimation by LAI-2000 under artificially changed leaf to wood area proportions. Biologia Plantarum, 43 (4): 537-544.

Pokorný, R., TomášKová, I., HavránKová, K. 2008: Temporal variation and efficiency of leaf area index in young mountain Norway spruce stand. European Journal of Forest Research, 127: 359-367. 
Ryan, M. G., Binkley, D., Fownes, J. H. 1997: Age-related decline in forest productivity: pattern and process. Advances in Ecological Research, 27: 213-262.

Sonohat, G., Balandier, P., Ruchaud, F. 2004: Predicting solar radiation transmittance in the understory of even-aged coniferous stands in temperate forests. Annals of Forest Science, 61: 629-641.

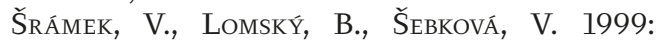
Působení abiotických faktorů na porosty náhradních dřevin. [Influence of abiotic factors on forests of substitute tree species] In: Sborník konference „Problematika zachování porostů náhradních drevin v imisní oblasti Krušných hor", Most 18.-19.5. 1999: 27-32.

ŠrÁMEK, V., SOUKUP, F., SLODIČÁK, M. ET AL. 2008: Chřadnutí lesních porostů na LS Jablunkov - Určení komplexu př́ičin poškozenía návrh opatření na revitalizaci lesa. [Decline of forest stands in Jablunkov - Determination of complex causing damages and draft action for forest revitalization]. Závérečná zpráva projektu Grantové služby LČR, VÚLHM Jiloviště Strnady.

Thomas, S. C., Ickes, K. 1995: Ontogenetic changes in leaf size in Malaysian rain forest trees. Biotropica, 27: 427-434.

Tolasz, R. (ed) 2007: Atlas podnebí Česka. [Atlas of climate of the Czech Republic] Praha a Olomouc, 1. vydání, 256 s., ISBN 978-80-86690-26-1.

Vertessy, R. A., Watson, F.G.R., O'Sullivan, S. K. 2001: Factors determining relations between stand age and catchment water balance in mountain ash forests. Forest Ecology and Management, 143: 13-26.

Vose, J. M., Dougherty, P. M., Long, J. N., Smith, F.W., Gholz, H. L., Curran, P. J. 1994: Factors influencing the amount and distribution of leaf area of pine stands. Ecological Bulletins, 43: 102-114. 